\title{
Needs Analysis in English for Academic Purposes: The Case of Teaching Assistants at the University of Khartoum
}

\section{Análisis de necesidades para inglés con propósitos académicos: el caso de los asistentes de docencia en la Universidad de Jartum*}

\author{
Abuelgasim Sabah Elsaid Mohammed \\ abuelgasims@gmail.com \\ Hala Salih Mohammed Nur \\ halasalih@uofk.edu \\ University of Khartoum, Khartoum, Sudan
}

This study aimed at investigating the English language needs of teaching assistants at the University of Khartoum, Sudan. The study focused on identifying the teaching assistants' purposes for learning English, and discovering the most important skills, language areas, and academic sub-skills they needed. The study also attempted to determine the teaching assistants' proficiency in the English language. To this end a quantitative approach was adopted. Data were collected through a questionnaire and a test. The results revealed that the teaching assistants needed English for their social life and academic purposes: to communicate with the outside world and to teach their students. The skills regarded as most important were writing and speaking. Finally, the level of proficiency of the participants in the English language was below the average in all the skills.

Key words: English for academic purposes, English for specific purposes, needs analysis, teaching assistants.

* $\quad$ Received: September 11, 2017. Accepted: February 16, 2018.

How to cite this article (APA 6th ed.):

Elsaid Mohammed, A. S., \& Nur, H. S. M. (2018). Needs analysis in English for academic purposes: The case of teaching assistants at the University of Khartoum. HOW, 25(2), 49-68. https://doi.org/10.19183/ how.25.2.409.

This article is licensed under a Creative Commons Attribution-NonCommercial-NoDerivatives 4.0 International License. License Deed can be consulted at https://creativecommons.org/licenses/by-nc-nd/4.0/. 
Este estudio indagó sobre las necesidades en el idioma inglés de asistentes docentes en la Universidad de Jartum, Sudán. Se identificaron los propósitos de los participantes para aprender inglés, así como las habilidades más importantes, las áreas del lenguaje y las destrezas académicas que ellos necesitaban. También se buscó determinar el nivel de comando del inglés de los participantes. Así, se adoptó un enfoque cuantitativo y los datos fueron recogidos con un cuestionario y una prueba. Los resultados revelaron que los participantes utilizan el inglés para socializar y con propósitos académicos: comunicarse con el mundo y enseñar a sus estudiantes. Las habilidades que se consideraron más relevantes fueron la escritura y el habla. Finalmente, el nivel de comando de inglés de los participantes estuvo por debajo del promedio en todas las habilidades.

Palabras clave: análisis de necesidades, asistentes docentes, inglés para propósitos académicos, inglés para propósitos específicos.

\section{Introduction}

Several reasons caused the existence of English for specific purposes (ESP) according to Hutchinson and Waters (1987). First, as Ibrahim (2017) states:

After the end of the Second World War, tremendous development happened in science, technology, and economics. This development was international, and consequently, an international language was required; due to the economic position of the United States, the English language became that language. (p. 1)

The second reason was the results of the linguistic research on language use which has shown that the language utilized by people when speaking or writing differs greatly from one situation to another; findings which have affected the teaching of English. Furthermore, because there are students with various specialties, it is natural that the language they use or need also varies from field to field. Another reason for the emergence of ESP has been the progress in educational psychology. Focusing on the learner revealed that learners have various needs, which may affect their motivation. A language course that meets learners' needs and concerns is "paramount" (Hutchison \& Waters, 1987).

English language learners are classified into two groups in Sudan. The first group encompasses professionals who attend courses in English for their job; the second one includes university students studying English language for academic purposes to read their field literature most of which is published in English (Hutchinson \& Waters, 1987; Lynch \& Hudson, 1991). This results in the fact that "learning English has become purposeful, not only for pleasure, but because it is the language of technology and commerce" (Ibrahim, 2017, p. 1). People who learn English language nowadays are conscious of why they learn it. 


\section{Statement of the Problem}

In Sudan, Arabic is the language of instruction in universities, but English is taught to undergraduate students as a university requirement in the first two academic years (Ibrahim, 2010). Ibrahim (2010) maintains that in the first year students learn General English (GE), and in the second year they study ESP. However, the ESP materials used for teaching students are not based on any kind of needs analysis. Consequently, the amount of English taught may not be enough to improve students' proficiency.

Despite these findings, most Master's programs at the University of Khartoum (U of K) are taught in the English language, and students are mostly required to write their theses in English. Additionally, courses of the Master's programs do not include an academic writing course to prepare students for writing their theses. Students, therefore, start writing their theses unaware of the requirements of writing academic English. This might lead to severe problems regarding students' writing performance.

\section{Questions of the Study}

This study aims to answer the following questions:

1. Why do the teaching assistants (TAs) at the U of $\mathrm{K}$ need the English language?

2. What are the most important macro skills/areas in the English language as believed by the TAs?

3. What are the most important academic sub-skills for the TAs?

4. What is the U of K TAs' current proficiency level of the English language?

\section{Theoretical Framework}

\section{English for Specific/Academic Purposes}

To begin with, ESP has many definitions. Strevens (1988) defines it in terms of characteristics, and he proposes two types: absolute and variable. The absolute characteristics, which are four, regard ESP as: First, designed to meet certain learners' needs; second, related to contents (in themes or topics) to particular specializations, occupations, or activities; third, focused on language suitable for those activities in syntax, discourse, semantics, and analysis of the discourse; finally, not like "general English". The variable characteristics are two: First, ESP may be limited to learning certain skills (reading only for instance); second, it may not be taught based on any methodology, which is pre-planned.

Robinson's (1991) definition is based on two important criteria and two characteristics. The two standards are that ESP is "normally goal-oriented" (p. 3) and that ESP courses rely 
on needs analysis that aim to determine what the students precisely need to do with the English language. In doing so, Robinson agrees with Hutchinson and Waters (1987) on the importance of needs analysis. ESP courses are taught in a limited period-during which course objectives should be attained — and are made up of groups of adult learners who have the same job or area of specialization (Robinson, 1991).

In their definition of ESP, Dudley-Evans and St John (1998) also employ absolute and variable characteristics. The absolute characteristics are three: (a) ESP is developed to cater to certain needs of the learner, (b) it uses the methodology and the tasks of the field it serves, and (c) it focuses on the language (grammar, lexis, and registers), skills, discourse, and genres suitable for these tasks.

The variable characteristics are four: (a) ESP may be related to or planned for a specific specialization; (b) it may apply a varied methodology from that of general English; (c) it is probably designed for adult learners either at university level or in a job situation, yet it could be taught to secondary school level students; and (d) it is designed for students with higher language levels (intermediate or advanced) because it anticipates basic knowledge of the language. However, it can be taught to beginners (Dudley-Evans \& St John, 1998).

ESP is generally divided into two main classes: English for academic purposes (EAP) and English for occupational purposes (EOP). EAP is further divided into four branches: English for science and technology (EST) has been the main branch; however, English for medical purposes (EMP) and English for legal purposes (ELP) have always had their place. English for management, finance, and economics (EMFE) is a recent branch, which has increasingly become important for Master of Business Administration Courses, but no specific acronym has been established for it (Dudley-Evans \& St John, 1998).

Hyland (2006) proposes that EAP has become popular due to the large numbers of international students studying in British and American universities. Therefore, these universities provide EAP courses (pre-sessional and in-sessional) to improve students' academic communication skills in English to match the standards required for university entry where English is the medium of instruction.

EAP caters to communication skills in the English language demanded in academic situations in official education systems for study reasons (ETIC as cited in Jordan, 1997). Similar to Robinson, Blue (as cited in Jordan, 1997) distinguishes between two types of EAP. Those courses aimed at general academic purposes are called English for general academic purposes (EGAP). They teach content of interest for a variety of academic fields. The other type is English for specific academic purposes (ESAP) which is oriented to students from a particular academic field.

Most ESP work can be done by EAP which, as we saw, is considered a branch of the former. It is teaching the language for specific purposes to those interested in joining 
academic studies. According to Robinson (1991), materials in EAP courses may be, "aimed at students from a wide variety of academic disciplines. Within such general courses, we might find components aimed at students from specific disciplines" (p. 100). EAP, according to Hyland (2006), is teaching English language for certain fields based on the social, intellectual, and linguistic requirements of the academic target situation. The teaching is oriented by a comprehension of texts and the restrictions in the situation.

\section{Definition and Importance of Needs Analysis (NA)}

Hutchinson and Waters (1987) differentiate between two types of needs. The first one is target needs, which refer to what students are required to do in the target situation. Target needs can be further divided into three classes. The first class refers to necessities, which means what students have to experience to perform in the target situation. The second class is lacks, which refers to the gap between what students already know and what is needed in the target situation. Finally, wants, which is used to refer to what students feel they need. The second type of needs proposed by Hutchinson and Waters is learning needs. This type involves taking into consideration how learners learn. Furthermore, it includes information about learners, reasons for learning the language, and the ESP course time and location (Hutchinson \& Waters, 1987).

Berwick (1989) states that NA is the assessable difference between a present situation and a future desired one. Similar to Nunan (1988), Berwick classifies needs into objective and subjective needs. He suggests that objective needs are elicited from various types of real data about students, their language use in authentic contexts in addition to their present language proficiency and problems. Subjective needs, on the other hand, are concerned with the learners' mental and emotional needs in the learning situation.

A number of scholars such as Hutchinson and Waters (1987), Nunan (1988), Brindley (1989), Robinson (1991), Brown (1995, 2009), Seedhouse (1995), West (1997), Graves (1999), Richards (2001), and Long (2005), agree that NA plays an important role in ESP or general English course design. Hutchinson and Waters (1987) state that, in fact, it is the consciousness of learners' needs that differentiates between ESP and general English. NA, therefore, is a main feature of ESP course design to the extent that Graves (1999) and Belcher (2009) suggest that NA should be considered as something which teachers can practice as a part of their teaching.

Ali (2011) states that NA is the cornerstone of ESP, and can produce a focused course. In addition, Richards (2001) outlines that ESP begins with the analysis of students' needs. Various learners have different needs; this imposes some restrictions on both ESP teachers and the ESP course. As for teachers, they should be limited to their students' needs as revealed by the NA. As far as the ESP course restrictions are concerned, Strevens (as cited in 
Richards, 2001) points out that NA confines ESP courses to specific content covering distinct basic language skills; vocabulary, grammar forms, and language functions; themes or topics, and communicative needs.

Astika (1999) states that NA is not only the starting point for materials development, but also guides selection of contents, assessment, and classroom activities. Richards (2001) explains that NA produces data, which can be used in a variety of ways such as evaluating a course, setting objectives, designing tests and assessment tools, and providing information about a program to an outside body or organization.

\section{Approaches to NA}

Various approaches can be identified to study NA (Ali, 2011; Kaewpet, 2009; Songhori, 2008). Ali (2011) proposes target situation analysis (TSA) and present situation analysis (PSA), which are basic constituents for analyzing students' language learning needs.

Target situation analysis (TSA). According to Songhori (2008), TSA was used by Chambers in 1980 when he attempted to clarify the terminology confusion. Chambers calls TSA "communication in the target situation". Kaewpet (2009) and Songhori (2008) agree that Munby (1978) employed this model when he introduced his communicative needs processor (CNP) in 1978. For Hutchinson and Waters (1987) the CNP marked the maturity of ESP. The machine for investigating any group of learners' needs had been provided, and course developers only had to run it.

West (1997) stated that TSA was the oldest approach to NA. It was used in the work of the Council of Europe in the 1970s. At that time, the language needs of the target situation were discovered by observing and investigating those situations, which already existed in that context. These needs were called necessities or objective needs since they acted as the target of language for specific purposes (LSP). TSA works at different points to identify priorities regarding the language to be taught (English, German, French, etc.), the skills in the chosen language (reading, speaking, writing, etc.), the situation, and the functions or activities (speaking on the phone, listening to lectures, etc.).

TSA can best be understood as a term that includes necessities, lacks, and wants (Hutchinson \& Waters, 1987). Target situation needs means what the learner is required to perform in the target situation. TSA depends on asking questions about the target situation and the attitudes of the participants toward that situation. TSA includes six main questions, which are further divided into several other questions. The main questions ask about the purposes for which the language is needed, how the language is used, the content areas, who is involved in the communication process, the context in which the language will be used, and the time when the language will be used (Hutchinson \& Waters, 1987). 
Robinson (1991) considers TSA as a concentration on what students need at the end of the course. Dudley-Evans and St John (1998) and Hyland (2006, p. 74) propose that TSA involves "objective, perceived, and product-oriented needs".

Present situation analysis (PSA). PSA, which may be seen as a complement to TSA (Robinson, 1991; West, 1997), is another NA approach. As mentioned above, TSA aims at identifying what learners should be able to do after the course whereas PSA seeks to establish what learners are like at the beginning of the course. Moreover, PSA shows the "weakness and strength in language, skills, and learning experience" (Dudley-Evans \& St John, 1998, p. 125), and PSA, therefore, provides the starting point of the course.

According to Songhori (2008), PSA was first introduced by Richterich and Chancerel in the 1980s to serve multiple purposes through providing information from many sources. For example, it derives data from students, the educational organization, and the professional establishment. To decide on learners' present situation in the language, placement tests could be used as a data source. Nevertheless, information about learners' years of learning English and educational level can provide sufficient data about their aptitudes.

NA should be seen as a combination of both TSA and PSA (Robinson, 1991). Furthermore, Hyland (2006) suggests that PSA provides both objective data (age, proficiency, previous learning experience) and subjective information (self-perceived needs, weaknesses, and strengths). Therefore, PSA refers to identifying students' current level of proficiency including lacks while TSA attempts to identify what students need to do in the target situation.

\section{NA Data Collection Instruments}

According to Ibrahim (2017), "there is a common agreement on the variety of the methods used to collect data in NA" (p. 3). Scholars such as Basturkmen (2010), Brown (1995, 2009), Long (2005), Hyland (2006), Richards (2001), Graves (1999), Dudley-Evans and St John (1998), and West (1997) concur that questionnaires, observations, interviews, and analysis of authentic spoken and written texts are instruments which could be adopted to investigate needs.

"Interviews are used to ask open-ended questions. They permit collecting private information from individuals" (Ibrahim, 2017, p. 3). Brown (1995) suggests that this leads to correct points of view. However, interviews have some limitations; Dudley-Evans and St John (1998) state that interviews need time to be conducted. This is because they should be employed to complement any other data collection tool such as questionnaires. To conduct an interview and to attain relevant data, researchers need to limit the time and record the interview on a tape.

Analyzing authentic texts is a means of conducting NA. It involves analyzing written texts, or audio and video recordings of lectures, meetings, or classroom activities. It offers 
information about the target situation by identifying the linguistic features of the situation (Dudley-Evans \& St John, 1998). Brown (1995) suggests that authentic texts may exist inside or outside the program location. Examining students' past evaluation is an example for information found inside program location, while conducting a literature review is an example for information that can be located outside. Texts analysis assists in identifying what learners should read and write if they use the language mainly for reading and writing (Dudley-Evans \& St John, 1998).

\section{Previous Studies}

Several studies have been conducted to assess teaching staff needs. Vahed (2017) analyzed the needs of 137 professors at three Iranian universities. The study adopted a questionnaire method for data collection. The study found a great demand for EAP and academic writing courses. This author also concluded that the professors had problems in academic writing.

Bedoya, Valencia, and Montoya (2015) investigated the needs of the professors, at a Colombian public university, for English language. Data were collected through a questionnaire, focus group, and interviews. The study found that the subjects wanted to be proficient in the English language to publish their research, and to get full-time teaching jobs. The professors were interested in developing oral and listening skills and using English when teaching their classes.

Bouabdallah (2015) analyzed the needs of first year Master's in biology students at the University of Tlemcen, Algeria. The study used a proficiency test, structured interviews, and a questionnaire of the students for data collection. The study revealed that students considered listening, speaking, and translating texts from English to Arabic as the most important skills. Students also wanted to understand lectures in English, read and translate scientific articles, and take part in oral discussion. Moreover, the subjects were not proficient in the English language. Writing and speaking were considered the most difficult skills for them.

Moattarian and Tahririan (2014) studied the language needs of tourism management graduates in Iran. The study used adopted a questionnaire of the students and a semi structured interview with the graduates, English language instructors, specialization instructors, and experts in tourism management. The study revealed that all four skills were considered important and needed to be emphasized for tourism students. Students were unable to communicate in the English language. The graduates showed that the previous ESP course was not helpful to them. All the subjects confirmed the importance of English in the field of tourism. 


\section{Method}

\section{Participants}

Teaching assistants are employed at the $\mathrm{U}$ of $\mathrm{K}$ according to their academic merits. They are usually those students who graduate with the highest degree. The participants in this study were 58 teaching assistants. The sample was selected based on the convenience sampling technique. The $\mathrm{U}$ of $\mathrm{K}$ teaching assistants (TAs) were invited to take a placement test to determine their level in order to prepare a training program in the English language for them. These 58 TAs were the first group to attend the test.

Section $\mathrm{A}$ in the questionnaire showed that the TAs work in 14 of the faculties in the $\mathrm{U}$ of $\mathrm{K}$. These 14 faculties represent $63.6 \%$ of the total of the faculties at the $\mathrm{U}$ of $\mathrm{K}$. The TAs graduated between 2008-2016 and their ages ranged from 22-35 years. There were 21 males $(36.2 \%)$ and 37 females (63.8\%). Forty-five of them (77.6\%) had only a BA or BSc, 12 $(20.7 \%)$ had a BA/BSc and MA/MSc, and one (1.7\%) had a BA/BSc and a Higher Diploma. Thirty-eight (84.4\%) were registered for a Master's Degree, one $(8.3 \%)$ was registered for a $\mathrm{PhD}$ degree, and three (6.7\%) were registered for a Higher Diploma.

\section{Instruments}

To collect data, a questionnaire and a proficiency test were used. The questionnaire was adapted from Gillet (2015). It contained four sections: Section A deals with background information such as sex, age, degree held, faculty, and year of graduation. Section B focuses on the reasons for the TAs needing the English language. The participants were given a five-point Likert scale survey ranging from strongly agree to not sure. Section $\mathrm{C}$ covers the importance of the four skills in addition to other areas such as general vocabulary, scientific vocabulary, and grammar. The fourth section, $\mathrm{D}$, asks about the importance of some subskills related to writing, reading, speaking, and listening.

As for the test, it was aimed at determining the TAs proficiency level and to decide on the problems they faced in the English language. The test contained four question sections. The first one was reading comprehension made up of a reading text followed by 10 multiple choice questions (MCQs). The second section focused on grammar, and contained 15 MCQs. The third question was listening and the last one was writing.

\section{Reliability}

According to Dörnyei (2003), data collection tools should score not less than 0.60 to be considered reliable. Table 1 shows the instruments reliability. 
Table 1. Instruments Reliability

\begin{tabular}{|l|c|c|c|}
\hline \multicolumn{1}{|c|}{ Instrument } & Cronbach's alpha & $\begin{array}{c}\text { No. of items } \\
\text { Reliability }\end{array}$ & $\begin{array}{c}\text { (Sqrt. of } \\
\text { Cronbach's alpha) }\end{array}$ \\
\hline $\begin{array}{l}\text { Students' } \\
\text { questionnaire }\end{array}$ & .884 & 57 & 0.94 \\
\hline Proficiency test & .713 & 4 & 0.84 \\
\hline
\end{tabular}

Taking into consideration that the acceptable reliability for an instrument is at least $(0.60)$, the study showed two instruments were reliable as shown in Table 1.

\section{Results and Discussion}

This section presents the results which are organized to answer the four research questions. In addition, the results are also discussed, and their implications are shown.

\section{Why Do the TAs at the U of K Need the English Language?}

Section B in the questionnaire sought to answer this research question. It asked the participants about the purposes for which they need English. It attempted to identify the purposes behind the TAs' need for the English language. The results are shown in Table 2.

Table 2. Purposes for Needing the English Language

\begin{tabular}{|c|l|c|c|c|c|c|c|c|c|}
\hline \multirow{2}{*}{ No. } & \multicolumn{2}{|c|}{ Purpose } & \multicolumn{2}{c|}{$\begin{array}{c}\text { Strongly } \\
\text { agree }\end{array}$} & \multicolumn{2}{c|}{$\begin{array}{c}\text { Strongly } \\
\text { disagree }\end{array}$} & \multicolumn{2}{c|}{ Not sure } & \multicolumn{2}{c|}{$\begin{array}{c}\text { Did not } \\
\text { answer }\end{array}$} \\
\cline { 3 - 13 } & & No. & $\%$ & No. & $\%$ & No. & $\%$ & No. & $\%$ \\
\hline 8 & Academic study & 55 & 94.8 & 3 & 5.2 & \multicolumn{2}{|c|}{0} & \multicolumn{2}{|c|}{0} \\
\hline 9 & Social life & 57 & 98.3 & \multicolumn{2}{|c|}{0} & \multicolumn{2}{|c|}{0} & 1 & 1.7 \\
\hline 10 & $\begin{array}{l}\text { Communication with } \\
\text { the outside world }\end{array}$ & 55 & 94.8 & 1 & 1.7 & 1 & 1.7 & 1 & 1.7 \\
\hline 11 & Teaching my students & 53 & 91.4 & 2 & 3.4 & \multicolumn{2}{|c|}{0} & 5 & 8.6 \\
\hline 12 & Getting a new job & 39 & 67.2 & 8 & 13.8 & 7 & 12.0 & 4 & 6.9 \\
\hline
\end{tabular}

As shown in Table 2, $(57,98.3 \%)$ of the participants who responded to this question strongly agreed that they needed English for social life. This purpose is followed by academic study and communication with the outside world since $(55,94.8 \%)$ of the TAs strongly agreed 
on both. Teaching students comes fourth as $(53,91.4 \%)$ of the subjects who answered the question strongly agreed on that. Getting a new job shows last in order because (39, 67.2\%) of the respondents strongly agreed on it. It seems that participants are aware of their need for English language for various purposes. However, the need of English for social life is extraordinary. This is because English is not used in everyday life in Sudan. This represents students" "wants" rather than needs. Hutchinson and Waters (1987) suggest that wants may vary from needs and contradict with them. The need of English for academic study is essential since $38(84.4 \%)$ of the TAs were studying for a Master's degree, and one (8.3\%) was studying for a $\mathrm{PhD}$. These results imply that the participants need English courses that enable them to communicate and study in the English language. These results agree with what was revealed by Vahed (2017), who concluded that his subjects needed EAP courses to prepare them for academic study. The results are also in line with Bedoya et al. (2015) who found that their students needed to be proficient in English to communicate with it.

\section{What Are the Most Important Macro Skills/Areas in English Language as Believed by the TAs?}

This question is covered in Items 10 to 13 in the questionnaire. The results are displayed in Table 3.

Table 3. Skills and Language Areas Importance

\begin{tabular}{|c|l|c|c|c|c|c|c|c|c|}
\hline \multirow{2}{*}{ No. } & \multirow{2}{*}{ Purpose } & \multicolumn{2}{|c|}{ Strongly agree } & \multicolumn{2}{c|}{$\begin{array}{c}\text { Strongly } \\
\text { disagree }\end{array}$} & \multicolumn{2}{c|}{ Not sure } & \multicolumn{2}{c|}{$\begin{array}{c}\text { Did not } \\
\text { answer }\end{array}$} \\
\cline { 3 - 12 } & & No. & $\%$ & No. & $\%$ & No. & $\%$ & No. & $\%$ \\
\hline 13 & Reading & 53 & 91.4 & 3 & 5.2 & 1 & 1.7 & 1 & 1.7 \\
\hline 14 & Writing & 56 & 96.6 & 1 & 1.7 & \multicolumn{2}{|c|}{0} & 1 & 1.7 \\
\hline 15 & Speaking & 55 & 94.8 & 2 & 3.4 & 1 & 1.7 & \multicolumn{2}{|c|}{0} \\
\hline 16 & Listening & 52 & 89.7 & 3 & 5.2 & 1 & 1.7 & 2 & 1.3 \\
\hline 17 & General vocabulary & 53 & 91.4 & 2 & 3.4 & 1 & 1.7 & 2 & 3.4 \\
\hline 18 & Scientific vocabulary & 50 & 86.2 & 3 & 5.2 & 2 & 3.4 & 3 & 3.4 \\
\hline 19 & Grammar & 50 & 86.2 & 6 & 10.3 & \multicolumn{2}{|c|}{0} & 2 & 3.4 \\
\hline
\end{tabular}

Table 3 shows that the most important skills are writing (56,96.6\%), speaking 55 $(94.8 \%)$, and reading and general vocabulary $(53,91.4 \%)$, respectively. These are followed by listening $(52,89.7 \%)$. These results suggest that the TAs, as postgraduate students, are fully conscious of the importance of writing for their studies, since most MA/MSc programs at 
the $\mathrm{U}$ of $\mathrm{K}$ require writing a partial thesis. Therefore, the results call for academic writing courses. Unfortunately, these courses are not offered. The importance of speaking represents the TAs' wants since it is not urgently needed. As put by Ibrahim (2017) 'it is normal to find difficulty in discovering students' needs when, theoretically, students need to read, but they may be interested in other skills" (p. 15), that is, "delayed needs rather than immediate needs" (Dudley-Evans \& St John, 1998, p. 40). Moreover, Robinson (1991) proposes that speaking skills are considered as criteria for measuring language proficiency. As for reading, it is considered important for academic purposes since it is needed because of its connection to writing theses. Generally, it can be stated that all the four skills are considered important in addition to general vocabulary, grammar, and scientific vocabulary. These results connote to that of Moattarian and Tahririan (2014) who revealed that all the four skills were important to their participants. The results contradict Bedoya et al. (2017) and Bouabdallah (2015), who concluded that only listening and speaking were important to their subjects.

\section{What Are the Most Important Academic Sub-Skills for the TAs?}

Items 20 to 67 in the questionnaire covered the sub-skills of the main four skills. Writing sub-skills are included in Items 20 to 35, and Table 4 presents the results.

Table 4. Writing Sub-Skills Importance

\begin{tabular}{|c|l|c|c|c|c|c|c|c|c|}
\hline \multirow{2}{*}{ Item } & \multirow{2}{*}{ Sub-skill } & \multicolumn{2}{|c|}{ Strongly agree } & \multicolumn{2}{|c|}{$\begin{array}{c}\text { Strongly } \\
\text { disagree }\end{array}$} & \multicolumn{2}{|c|}{ Not sure } & \multicolumn{2}{|c|}{$\begin{array}{c}\text { Did not } \\
\text { answer }\end{array}$} \\
\cline { 3 - 10 } & & No. & $\%$ & No. & $\%$ & No. & $\%$ & No. & $\%$ \\
\hline 20 & $\begin{array}{l}\text { Writing correct } \\
\text { sentences }\end{array}$ & 53 & 91.4 & 3 & 5.2 & & & 2 & 3.4 \\
\hline 21 & $\begin{array}{l}\text { Writing } \\
\text { grammatically }\end{array}$ & 51 & 87.9 & 5 & 8.6 & & 2 & 3.4 \\
\hline 22 & $\begin{array}{l}\text { Linking sentences } \\
\text { in writing }\end{array}$ & 47 & 81.0 & 4 & 4.7 & 3 & 5.2 & 4 & 6.9 \\
\hline 23 & Spelling & 55 & 94.8 & 1 & 1.7 & & 0 & 2 & 3.4 \\
\hline 24 & Punctuation & 43 & 74.1 & 4 & 6.9 & 6 & 10.3 & 5 & 8.6 \\
\hline 25 & $\begin{array}{l}\text { Use of appropriate } \\
\text { style }\end{array}$ & 46 & 79.3 & 5 & 8.6 & 3 & 5.2 & 4 & 6.9 \\
\hline 26 & $\begin{array}{l}\text { Creating well- } \\
\text { structured } \\
\text { paragraphs }\end{array}$ & 47 & 81.0 & 2 & 3.4 & 3 & 5.2 & 6 & 10.3 \\
\hline
\end{tabular}


Needs Analysis in English for Academic Purposes:

The Case of Teaching Assistants at the University of Khartoum

\begin{tabular}{|c|c|c|c|c|c|c|c|c|c|}
\hline \multirow[t]{2}{*}{ Item } & \multirow[t]{2}{*}{ Sub-skill } & \multicolumn{2}{|c|}{ Strongly agree } & \multicolumn{2}{|c|}{$\begin{array}{l}\text { Strongly } \\
\text { disagree }\end{array}$} & \multicolumn{2}{|c|}{ Not sure } & \multicolumn{2}{|c|}{$\begin{array}{l}\text { Did not } \\
\text { answer }\end{array}$} \\
\hline & & No. & $\%$ & No. & $\%$ & No. & $\%$ & No. & $\%$ \\
\hline 27 & $\begin{array}{l}\text { Writing research } \\
\text { proposal }\end{array}$ & 52 & 89.7 & 4 & 6.9 & 1 & 1.7 & 1 & 1.7 \\
\hline 28 & $\begin{array}{l}\text { Writing literature } \\
\text { review }\end{array}$ & 50 & 86.2 & 2 & 3.4 & \multicolumn{2}{|c|}{0} & 6 & 10.3 \\
\hline 29 & $\begin{array}{l}\text { Writing abstracts, } \\
\text { introductions, } \\
\text { and conclusions }\end{array}$ & 51 & 87.9 & 2 & 3.4 & 1 & 1.7 & 4 & 6.9 \\
\hline 30 & $\begin{array}{l}\text { Organizing and } \\
\text { planning writing }\end{array}$ & 47 & 81.0 & 3 & 5.2 & 2 & 3.4 & 6 & 10.3 \\
\hline 31 & $\begin{array}{l}\text { Acknowledging } \\
\text { sources }\end{array}$ & 48 & 82.8 & 4 & 6.9 & \multicolumn{2}{|c|}{0} & 6 & 10.3 \\
\hline 32 & $\begin{array}{l}\text { Writing a list } \\
\text { of references }\end{array}$ & 46 & 79.3 & 6 & 10.3 & 2 & 3.4 & 4 & 6.9 \\
\hline 33 & Avoiding plagiarism & 43 & 74.1 & 5 & 8.6 & 6 & 10.3 & 4 & 6.9 \\
\hline 34 & $\begin{array}{l}\text { Including tables, } \\
\text { graphs and } \\
\text { diagrams }\end{array}$ & 43 & 74.1 & 5 & 8.6 & 5 & 8.6 & 5 & 8.6 \\
\hline 35 & $\begin{array}{l}\text { Choosing } \\
\text { appropriate } \\
\text { vocabulary }\end{array}$ & 43 & 74.1 & 4 & 6.9 & 3 & 5.2 & 8 & 13.8 \\
\hline
\end{tabular}

From Table 4, the most important writing sub-skills are spelling (55, 94.8\%); writing correct sentences (53, 91.4\%); writing literature review (50, 89,7\%); writing abstracts, introductions, and conclusions (51, 87.9\%); acknowledging sources (48, 82.8\%); and writing grammatically $(51,87.9 \%)$. The other writing sub-skills range between 74.1 $79.3 \%$. It is noticeable that spelling depends on students' own exposure to the language and as for writing literature review, it is essential for research writing which is required by the master's courses. Writing correct sentences is very important for good writing. The results imply that both general and academic sub-skills are regarded as important by the TAs. The results also imply that an academic writing course should cover all these subskills to equip the TAs with the necessary academic writing skills. Generally, as attested by the high percentages of those who strongly agreed, all the other writing sub-skills are considered important. These results match with what was found by Vahed (2017) and Bedoya et al. (2015) who concluded that their subjects needed academic writing courses to prepare them to write scientific papers. 
Concerning the academic reading sub-skills (Items 37-48) the results are displayed in Table 5.

Table 5. Reading Sub-Skills Importance

\begin{tabular}{|c|c|c|c|c|c|c|c|c|c|}
\hline \multirow[t]{2}{*}{ Item } & \multirow[t]{2}{*}{ Sub-skill } & \multicolumn{2}{|c|}{$\begin{array}{l}\text { Strongly } \\
\text { agree }\end{array}$} & \multicolumn{2}{|c|}{$\begin{array}{l}\text { Strongly } \\
\text { disagree }\end{array}$} & \multicolumn{2}{|c|}{ Not sure } & \multicolumn{2}{|c|}{$\begin{array}{l}\text { Did not } \\
\text { answer }\end{array}$} \\
\hline & & No. & $\%$ & No. & $\%$ & No. & $\%$ & No. & $\%$ \\
\hline 37 & Reading textbooks & 54 & 93.1 & \multicolumn{2}{|c|}{0} & \multicolumn{2}{|c|}{0} & 4 & 6.9 \\
\hline 38 & Reading journal articles & 53 & 91.4 & \multicolumn{2}{|c|}{0} & 2 & 3.4 & 3 & 5.8 \\
\hline 39 & $\begin{array}{l}\text { Reading magazine or } \\
\text { newspaper articles }\end{array}$ & 51 & 87.9 & \multicolumn{2}{|c|}{0} & 3 & 5.2 & 4 & 6.9 \\
\hline 40 & Reading handouts & 47 & 81.0 & \multicolumn{2}{|c|}{0} & 4 & 6.9 & 7 & 12.0 \\
\hline 41 & $\begin{array}{l}\text { Reading to get specific } \\
\text { information for assignments }\end{array}$ & 51 & 87.9 & 3 & 5.2 & 1 & 1.7 & 3 & 5.2 \\
\hline 42 & Reading to check information & 53 & 91.4 & 1 & 1.7 & 1 & 1.7 & 3 & 5.2 \\
\hline 43 & Reading to support a position & 51 & 87.9 & 2 & 3.4 & 1 & 1.7 & 4 & 6.9 \\
\hline 44 & Reading critically & 47 & 81.0 & 3 & 5.2 & 3 & 5.2 & 5 & 8.6 \\
\hline 45 & Reading quickly and efficiently & 50 & 86.2 & 3 & 5.2 & 2 & 3.4 & 3 & 5.2 \\
\hline 46 & Understanding vocabulary & 50 & 86.2 & 3 & 5.2 & 1 & 1.7 & 3 & 5.2 \\
\hline 47 & $\begin{array}{l}\text { Reading and answering } \\
\text { questions }\end{array}$ & 53 & 91.4 & 3 & 5.2 & 1 & 1.7 & 1 & 1.7 \\
\hline 48 & Taking notes & 46 & 79.3 & 4 & 6.9 & 4 & 6.9 & 4 & 6.9 \\
\hline
\end{tabular}

Table 5 shows that reading textbooks is the most important reading sub-skill as all the participants who gave an answer to this item (54, 93.1\%) strongly agreed on it. It is followed by reading journal articles, reading to check information (53, $91.4 \%$ ), reading magazine or newspaper articles, reading to support position (51, 87.9\%); reading and answering questions $(53,91.4 \%)$, understanding vocabulary; and reading quickly and efficiently (50, 86.2\%). Most of these sub-skills are related to academic writing. The results suggest that an academic reading course that teaches all these sub-skills is strongly recommended to prepare the TAs for their academic studies in the future. The results of this study, concerning reading subskills, are unique because the previous studies did not cater to them.

As for speaking sub-skills, they were included in items 50 to 56 in the questionnaire. The results show that the most important speaking sub-skills were, asking and answering questions, speaking in groups since $54(93.1 \%)$ of the subjects who responded to this item 
strongly agreed on both sub-skills. These are followed by speaking accurately $(53,91.4 \%)$, speaking to class (reporting results) $(52,89.7 \%)$, giving presentations $(51,87.9 \%)$, and asking for information (50, 86.2\%), (see Table 6).

Table 6. Speaking Sub-Skills Importance

\begin{tabular}{|c|l|c|c|c|c|c|c|c|c|c|}
\hline \multirow{2}{*}{ Item } & \multicolumn{2}{|c|}{ Sub-skill } & \multicolumn{2}{c|}{$\begin{array}{c}\text { Strongly } \\
\text { agree }\end{array}$} & \multicolumn{2}{c|}{$\begin{array}{c}\text { Strongly } \\
\text { disagree }\end{array}$} & \multicolumn{2}{|c|}{ Not sure } & \multicolumn{2}{c|}{$\begin{array}{c}\text { Did not } \\
\text { answer }\end{array}$} \\
\cline { 3 - 13 } & & No. & $\%$ & No. & $\%$ & No. & $\%$ & No. & $\%$ \\
\hline 50 & $\begin{array}{l}\text { Asking/Answering } \\
\text { questions in class }\end{array}$ & 54 & 93.1 & 2 & 3.4 & \multicolumn{2}{|c|}{0} & 2 & 3.4 \\
\hline 51 & Speaking in groups & 54 & 93.1 & 2 & 3.4 & 1 & 1.7 & 1 & 1.7 \\
\hline 52 & $\begin{array}{l}\text { Speaking to class (e.g., } \\
\text { reporting results) }\end{array}$ & 52 & 89.7 & 2 & 3.4 & 1 & 1.7 & 3 & 5.8 \\
\hline 53 & Giving presentations & 51 & 87.9 & 1 & 1.7 & 3 & 5.8 & 3 & 5.8 \\
\hline 54 & Asking for information & 50 & 86.2 & 1 & 1.7 & 1 & 1.7 & 6 & 10.3 \\
\hline 55 & Speaking accurately & 53 & 91.4 & 2 & 3.4 & 0 & 3 & 5.8 \\
\hline 56 & Correct pronunciation & 45 & 77.9 & 4 & 6.9 & 2 & 3.4 & 7 & 12.0 \\
\hline
\end{tabular}

The results indicate that all speaking sub-skills are important. This is natural because the language of instruction in the Master's programs at the $\mathrm{U}$ of $\mathrm{K}$ is the English language. Thus, it is important for the students to speak English well. Students need training in these various skills to be able to cope with their study. The results also indicate that a strong training course on academic speaking seems necessary.

The last set of academic sub-skills belongs to listening and it is covered by Items 58 to 67 in the questionnaire. The results are displayed in Table 7.

Table 7. Listening Sub-Skills Importance

\begin{tabular}{|c|c|c|c|c|c|c|c|c|c|}
\hline \multirow[t]{2}{*}{ Item } & \multirow[t]{2}{*}{ Sub-skill } & \multicolumn{2}{|c|}{ Strongly agree } & \multicolumn{2}{|c|}{$\begin{array}{l}\text { Strongly } \\
\text { disagree }\end{array}$} & \multicolumn{2}{|c|}{ Not sure } & \multicolumn{2}{|c|}{$\begin{array}{l}\text { Did not } \\
\text { answer }\end{array}$} \\
\hline & & No. & $\%$ & No. & $\%$ & No. & $\%$ & No. & $\%$ \\
\hline 58 & Listening in lectures & 53 & 91.4 & & & 1 & 1.7 & 4 & 6.9 \\
\hline 59 & $\begin{array}{l}\text { Listening in seminars } \\
\text { and discussions }\end{array}$ & 55 & 94.8 & & & & & 3 & 5.2 \\
\hline
\end{tabular}




\begin{tabular}{|c|l|c|c|c|c|c|c|c|c|}
\hline \multirow{2}{*}{ Item } & \multirow{2}{*}{ Sub-skill } & \multicolumn{2}{|c|}{ Strongly agree } & \multicolumn{2}{c|}{$\begin{array}{l}\text { Strongly } \\
\text { disagree }\end{array}$} & \multicolumn{2}{c|}{ Not sure } & \multicolumn{2}{c|}{$\begin{array}{c}\text { Did not } \\
\text { answer }\end{array}$} \\
\cline { 3 - 11 } & & No. & $\%$ & No. & $\%$ & No. & $\%$ & No. & $\%$ \\
\hline 60 & Listening to recorded speech & 49 & 84.5 & 4 & 6.9 & \multicolumn{2}{|c|}{0} & 5 & 8.6 \\
\hline 61 & Following instructions & 48 & 82.8 & 1 & 1.7 & 4 & 6.9 & 5 & 8.6 \\
\hline 62 & Watching films/videos & 50 & 86.2 & 1 & 1.7 & 3 & 5.2 & 4 & 6.9 \\
\hline 63 & Understanding main points & 50 & 86.2 & 2 & 3.4 & 2 & 3.4 & 4 & 6.9 \\
\hline 64 & $\begin{array}{l}\text { Listening to get specific } \\
\text { information for assignments }\end{array}$ & 49 & 84.5 & 1 & 1.7 & 3 & 5.2 & 5 & 8.6 \\
\hline 65 & Understanding vocabulary & 53 & 91.4 & 3 & 5.2 & & 0 & 2 & 3.4 \\
\hline 66 & $\begin{array}{l}\text { Listening and } \\
\text { answering questions }\end{array}$ & 51 & 78.9 & 1 & 1.7 & 2 & 3.4 & 4 & 6.9 \\
\hline 67 & Taking notes & 47 & 81.0 & 3 & 5.2 & 3 & 5.2 & 5 & 8.6 \\
\hline
\end{tabular}

\section{What Is the TAs Present Situation in the English Language?}

Present situation refers to the respondents' proficiency level in the English language. To reveal the TAs present situation in English, their results on the placement test were analyzed and are shown in Table 8.

Table 8. The TAs' Means \& Standard Deviation on the Placement Test

\begin{tabular}{|l|c|c|c|}
\hline \multicolumn{1}{|c|}{ Skill } & Total score & Means & SD \\
\hline Reading & 15 & 9.48 & 3.61 \\
\hline Grammar & 10 & 2.98 & 1.249 \\
\hline Listening & 10 & 6.27 & 2.198 \\
\hline Writing & 15 & 5.13 & 2.543 \\
\hline Total & 50 & 23.87 & 7.46 \\
\hline
\end{tabular}

As seen in Table 8, the TAs' proficiency is below average as the total means is 23.87 . They were weak in grammar $(M=2.98)$, average in listening $(M=6.27)$ and writing $(M=5.13)$. However, reading was the best skill $(M=9.48)$. This can be attributed to the fact that the reading questions were direct, and they did not require high level thinking. Also, the TAs had a lot of training in reading during their previous study of English language. Surprisingly, grammar is the weakest language area although they studied it extensively in secondary school and university courses. This might have been caused by the fact that the TAs were not in contact with grammar for a long 
time. Concerning listening, the TAs are average. This skill was not focused on in any previous English courses they had studied. As for writing, the TAs suffered from many problems such as sentence structure, subject verb agreement, use of correct vocabulary, style, and punctuation. It could be stated that the TAs' level of proficiency is below average. This may be due to the weak English syllabus in the secondary school and university. Another reason is that the time allotted for English courses is not enough to improve students' level of proficiency. Use of Arabic as the language of instruction in the university can be an additional reason for this level. These results match with what was revealed by Bedoya et al. (2015) and Bouabdallah (2015), who concluded that their participants were not proficient in English. Similar to the results of this study, Moattarian and Tahririan (2014) found that the previous courses taken by their participants were not useful.

The questionnaire contained open-ended questions asking the participants to list some sub-skills not listed in the questionnaire. These were Items 36 for writing sub-skills, 49 for reading, 57 for speaking, and 68 for listening. Ten (17.2\%) of the participants responded to these items. For Item 36, the TAs suggested writing stories, recommendation letters, formal emails, scientific papers, and publishing papers.

Concerning reading sub-skills, the participants proposed including reading literature and stories, reading discussion of scientific papers and theses discussion, reading general books, reading any material related to English, and reading for research purposes.

For speaking, the TAs suggested creating English clubs, establishing communication with students and others, speaking with foreigners confidently. For listening, one participant proposed listening to audios. These suggestions imply that the TAs are motivated to learn the English language to improve their proficiency level. This means that they are, generally, aware of the importance of English for them, and they are, specifically, aware of the importance of speaking. In addition, the results suggest that the participants are ready to exert effort in learning English due to the proposal of introducing English clubs which require time for attendance and some work to be prepared on the TAs part to participate in the clubs.

\section{Conclusion and Recommendations}

This study attempted to investigate the U of K TAs' academic needs for the English language. Precisely, the study sought to identify answers to the following questions. First, why do TAs at the $\mathrm{U}$ of $\mathrm{K}$ need the English language? The results showed that the TAs need English for social life, communication with the outside world, academic purposes, and to teach their students. Second, what are the most important macro skills/areas in the English language according to the TAs? As revealed by the results, the most important skills were writing and speaking. However, reading and listening were found to be important as well, in addition to general vocabulary and grammar. Third, what are the most important academic sub-skills for the TAs? It was found that all the sub-skills related to the four main skills 
were regarded as important to the TAs. Finally, what is the U of K TAs' current proficiency in the English language? The results disclosed that the current level of proficiency of the respondents was below average in all the skills, and that they were weak in grammar.

Based on these results, the following recommendations can be posed:

- The curriculum in secondary school must be revised. This is because when students are admitted to university, they suffer a lot in learning the English language due to weakness in the secondary school English curriculum which focuses mainly on grammar.

- The $\mathrm{U}$ of $\mathrm{K}$ must revisit its English language teaching policy in terms of time and syllabus. Due to the researchers' experience in teaching English at the U of $\mathrm{K}$, teaching English to more than 50 students in one class for two hours a week is insufficient to develop students' proficiency. Similarly, the absence of a clear syllabus with obviously articulated aims and learning outcomes is another issue that needs revision.

- The U of $\mathrm{K}$ must provide academic English courses covering the four skills in addition to vocabulary and grammar for its TAs, to prepare them for their future study. These courses could be considered as in-service training for the TAs trying to bridge the gap in the TAs' proficiency while equipping them with the necessary skills required for the academic world.

- The U of K should assist the English Language Institute to inaugurate its Diploma in English for Academic Purposes (DEAP), which can fill the gap in EAP teaching in Sudan. This DEAP was prepared by the Graduate Unit, ELI, and was designed taking into consideration the situation of the English language at the U of $\mathrm{K}$. It is built of a number of modules that aim at enhancing learners' proficiency first and then academic skills (speaking, listening, reading, and writing). Nevertheless, due to certain administrative obstacles and differences in points of view it was not agreed on to be launched.

\section{References}

Ali, A. A. (2011). A needs analysis for designing an ESP syllabus for the students of Sudan Naval Academy (Doctoral dissertation). Al Neelain University, Khartoum, Sudan.

Astika, G. (1999). The role of needs analysis in English for specific purposes. TEFLIN Journal, 10(1), 31-47.

Basturkmen, H. (2010). Developing courses in English for specific purposes. Basingstoke, UK: Palgrave Macmillan. https://doi.org/10.1057/9780230290518.

Bedoya, P. A., Valencia, L. M., \& Montoya, J. C. (2015). Students' needs analysis in an EFL programme for university professors. HOW, 22(2), 11-36. https://doi.org/10.19183/ how.22.2.118. 
Belcher, D. (2009). What ESP is and can be? An introduction. In D. Belcher (Ed.), English for specific purposes in theory and practice (pp. 1-20). Ann Arbor, US: University of Michigan Press. https:// doi.org/10.3998/mpub.770237.

Berwick, R. (1989). Needs assessment in language programming: From theory to practice. In R. K. Johnson (Ed.), The second language curriculum (pp. 48-62). Cambridge, UK: Cambridge University Press. https://doi.org/10.1017/CBO9781139524520.006.

Bouabdallah, F. H. (2015). A course design in ESP: The case of Master's students in the Department of Biology, University of Tlemcen (Master's thesis). University of Tlemcen, Algeria.

Brindley, G. (1989). The role of needs analysis in adult ESL programme design. In R. K. Johnson (Ed.), The second language curriculum (pp. 63-78). Cambridge, UK: Cambridge University Press. https://doi.org/10.1017/CBO9781139524520.007.

Brown, J. D. (1995). The elements of language curriculum: A systematic approach to programme development. Boston, US: Heinle \& Heinle.

Brown, J. D. (2009). Foreign and second language needs analysis. In M. H. Long \& C. J. Doughty (Eds.), The handbook of language teaching (pp. 269-293). London, UK: Wiley-Blackwell. https:// doi.org/10.1002/9781444315783.ch16.

Dörnyei, Z. (2003). Questionnaires in second language research: Construction, administration, and processing. London, UK: Lawrence Erlbaum Associates.

Dudley-Evans, T., \& St John, M. J. (1998.). Developments in English for specific purposes: A multi-disciplinary approach. Cambridge, UK: Cambridge University Press.

Gillet, A. (2015). Using English for academic purposes for students in higher education [Website]. Retrieved from www.uefap.org/resources.

Graves, C. (1999). Designing language courses: A guide for teachers. Boston, UK: Heinle \& Heinle.

Hutchinson, T., \& Waters, A. (1987). English for specific purposes: A learning-centred approach. Cambridge, UK: Cambridge University Press. https://doi.org/10.1017/CBO9780511733031.

Hyland, K. (2006). English for academic purposes: An advanced resource book. London, UK: Routledge.

Ibrahim, A. M. (2010). ESP at the tertiary level: Current situation, application, and expectation. English language Teaching, 3(1), 200-204. https://doi.org/10.5539/elt.v3n1p200.

Ibrahim, A. M. (2017). Specialization professors' perception on their students' needs for ESP: PEH students' case. English for Specific Purposes World, 54(19), 1-22.

Jordan, R. R. (1997). English for academic purposes: A guide and resource book for teachers. Cambridge, UK: Cambridge University Press. https://doi.org/10.1017/CBO9780511733062.

Kaewpet, C. (2009). A framework for investigating learner needs: Needs analysis extended to curriculum development. Electronic Journal of Foreign Language Teaching, 6(2), 209-220.

Long, M. H. (2005). Methodological issues in learner needs analysis. In M. H. Long (Ed.), Second language needs analysis (pp. 19-75). Cambridge, UK: Cambridge University Press. https://doi. org/10.1017/CBO9780511667299.002. 
Lynch, B., \& Hudson, T. (1991). EST reading. In M. Celce-Murcia (Ed.), Teaching English as a second or foreign language (2nd ed., pp. 216-230). Boston, US: Heinle \& Heinle.

Moattarian, A. M., \& Tahririan, M. H. (2014). Language needs of graduate students and ESP courses: The case of tourism management in Iran. Journal of Research in Applied Linguistics, 5(2), 4-22. Retrieved from http://rals.scu.ac.ir/article_11009_1201.html.

Munby, J. (1978). Communicative syllabus design. Cambridge, UK: Cambridge University Press.

Nunan, D. (1988). Syllabus design. Oxford, UK: Oxford University Press.

Richards, J. C. (2001). Curriculum development in language teaching. Cambridge, UK: Cambridge University Press. https://doi.org/10.1017/CBO9780511667220.

Robinson, P. (1991). ESP today: A practitioner's guide. New York, US: Prentice Hall International.

Seedhouse, P. (1995). Needs analysis and the general English classroom. ELT Journal, 49(1), 59-65. https://doi.org/10.1093/elt/49.1.59.

Songhori, M. H. (2008). Introduction to needs analysis. English for Specific Purposes World, 4(20), $1-25$.

Strevens, P. (1988). ESP after twenty years: A re-appraisal. In M. Tickoo (Ed.), ESP. State of the art (pp. 1-13). Singapore, SG: SEAMEO Regional Centre.

Vahed, S. T. (2017). The analysis of faculty needs to English for academic purposes in a middleeastern context. The Journal of Teaching English for Specific and Academic Purposes, 5(1), 77-86.

West, R. (1997). Needs analysis: State of the art. In R. Howard \& G. Brown (Eds.), Teacher education for languages for specific purposes (pp. 68-97). London, UK: Multilingual Matters.

\section{The Authors}

Abuelgasim Sabah Elsaid Mohammed is an assistant professor at the University of Khartoum. Currently he is on leave and works at Prince Sattam Bin Abdulaziz University in the Kingdom of Saudi Arabia. His interests are ESP, EAP, EFL, academic writing, materials design, and evaluation.

Hala Salih Mohammed Nur is an associate professor at the University of Khartoum. She is the founding director of the English Language Institute, the first training institute of its kind in Sudan. Here interests are teacher training, CALL, and teaching English to young learners. 